\title{
Role of tissue factor in thrombosis in antiphospholipid antibody syndrome
}

\author{
J Boles and $\mathbf{N}$ Mackman \\ Division of Hematology/Oncology, Department of Medicine, University of North Carolina at \\ Chapel Hill, Chapel Hill, NC, USA
}

\begin{abstract}
Antiphospholipid syndrome (APS) is an acquired autoimmune disorder defined by the presence of an antiphospholipid antibody (aPL) and the occurrence of at least one associated clinical condition that includes venous thrombosis, arterial thrombosis or pregnancy morbidity. The aPL detected in APS have long been thought to have a direct prothrombotic effect in vivo. However, the pathophysiology underlying their coagulopathic effect has not been defined. Emerging data suggest a role for the procoagulant protein tissue factor (TF). In this review we provide an overview of TF, describe mouse models used in the evaluation of the role of TF in thrombosis, as well as summarize recent work on TF and APS.
\end{abstract}

\section{Keywords}

antiphospholipid syndrome; thrombosis; coagulation; tissue factor; DIC

\section{Tissue factor}

Tissue factor (TF) is a transmembrane glycoprotein that is a member of the cytokine receptor super-family. TF was so named after it was noted that a component of tissue, when added to plasma, enhanced coagulation. TF was first purified in 1985 and was cloned soon thereafter. $1^{-4}$ The crystal structure of the TF extracellular domain bound to Factor VIIa (FVIIa) was reported in $1996.5 \mathrm{TF}$ is a 263 amino acid protein with three major domains: (1) an extracellular domain which binds to FVII/ FVIIa and substrates;2 (2) a transmembrane domain that serves as a membrane anchor; and (3) a short cytoplasmic carboxy terminal domain. TF serves as the primary initiator of in vivo coagulation. The TF/FVIIa complex activates FIX and FX and leads to thrombin and fibrin generation. Notably FVIIa is a weak serine protease on its own, but upon binding TF, its catalytic activity is increased $2 \times 10^{7}$ fold. ${ }^{6}$

TF is expressed constitutively by adventitial cells surrounding blood vessels and rapidly initiates coagulation after vessel injury.7,8 This perivascular localization was described as a hemostatic envelope by Drake and colleagues. ${ }^{9}$ In contrast to the high levels of TF in perivascular cells, vascular cells and blood cells do not express TF under normal conditions. However, there are very low levels of TF (commonly referred to as 'circulating TF' or 'blood borne TF') detectable in the blood of healthy individuals. ${ }^{10,11}$ It was initially argued

(c) The Author(s), 2010.

Correspondence to: Nigel Mackman, PhD, Division of Hematology/Oncology, Department of Medicine, University of North Carolina at Chapel Hill, Chapel Hill, NC 27599-7005, USA. nmackman@ med.unc.edu.

Reprints: http://www.sagepub.com/journalsReprints.nav 
that circulating TF represented a pool of TF that was able to be delivered continuously to developing thrombi and participate in its continued growth and extension.12 However, others felt that the levels of circulating TF in healthy individuals are too low to contribute to thrombosis.10 A soluble form of TF has also been described in the literature that is generated by alternative splicing. Importantly, this form of TF lacks the transmembrane domain and substrate binding site and does not possess procoagulant activity. ${ }^{11,13}$ Hoffman et al. ${ }^{14}$ noted that TF was present throughout thrombotic clots, whereas it was present only at the edges of hemostatic clots. The authors therefore argued that circulating TF is incorporated into thrombotic clots but their study did not determine whether this TF was active. Circulating TF remains an area of active investigation.

It has also been demonstrated that TF is expressed in a tissue-specific manner with high levels detected in various organs, such as the brain, heart, kidney and placenta. ${ }^{9,15-19}$ Animal models have shown that either a genetic deficiency or inhibition of TF in wild-type mice results in tissue-specific hemorrhage. ${ }^{20,21}$ Several groups also demonstrated that deletion of the TF gene results in embryonic lethality in mice. ${ }^{22-24}$ These data indicate that TF-dependent thrombin generation is essential for hemostasis.

While normal TF expression is required for maintaining hemostasis, pathologic TF expression can result in arterial thrombosis, venous thromboembolism (VTE) and disseminated intravascular coagulation (DIC). Elevated levels of circulating TF are observed in a variety of diseases including sepsis, diabetes, cardiovascular disease and cancer. ${ }^{25}$ It has been posited that thrombosis in these diseases may be triggered by TF. In blood TF is associated with microparticles (MP), and this form of TF will be referred to as TF-positive $\mathrm{MP}\left(\mathrm{TF}^{+} \mathrm{MP}\right)$. These are submicron fragments of cell membranes that are derived from activated/ apoptotic cells and retain cell proteins of their cellular origin. $26 \mathrm{TF}$ expression by monocytes is induced by exposure to various agents, including bacterial endotoxin (lipopolysaccharide [LPS]) stimulation. ${ }^{27}$ However, the presence of low levels of TF on platelets is more controversial. Various explanations for platelet TF include: (1) binding or uptake of $\mathrm{TF}^{+} \mathrm{MP}$ released by other cells into the blood; and (2) de novo synthesis of $\mathrm{TF}^{28-}$ 30 However, other authors were unable to detect TF activity or antigen on resting and calcium ionophore stimulated platelets. $8,10,31$ Similarly, there is disagreement related to the presence or absence of TF on granulocytes. One group reported that granulocytes express TF upon stimulation, ${ }^{32}$ and others describe TF expression on eosinophils ${ }^{33}$ and neutrophils. ${ }^{34}$ However, Osterud and colleagues could not detect TF expression in granulocytes but found that granulocytes acquire monocyte-derived $\mathrm{TF}^{+} \mathrm{MP}$ in whole blood. ${ }^{35}$

Another controversial issue regarding TF is the so-called 'encryption-decryption process'. Potential mechanisms for decryption have been discussed and reviewed previously. ${ }^{36}$ The observation that lysis of TF-positive cells results in a significant increase in TF activity, led to the proposal that TF exists in two states, a low-activity state, or 'encrypted', and a highactivity state, or 'decrypted'. One proposed mechanism is that interaction of TF with the membrane phospholipid phosphatidylserine (PS) increases its activity. PS is an anionic phospholipid that is normally maintained in an energy-dependent asymmetric state on the inner membrane leaflet but is exposed on the outer leaflet upon cell stimulation or membrane disruption. Another hypothesis for decryption was put forth by Chen et al. in 2006. They suggested that high TF activity required the formation of an allosteric disulfide bond between cysteine residues 186 and 209. ${ }^{37}$ Recently, however, Bach and Monroe have questioned this model based upon crystal structure. They argue that the two cysteine residues are obscured by the interaction between TF and FVIIa and therefore an enzyme, such as protein disulfide isomerase, cannot gain access to the residues to form the disulfide bond38. Although the mechanism for decryption remains ill-defined, the most likely mechanism appears to be via an interaction with PS. 


\section{Arterial thrombosis}

Arterial thrombosis, in the form of myocardial infarction and stroke, represents one of the most common causes of mortality in the US. The primary etiology of arterial thrombosis is instability or rupture of an atherosclerotic plaque. This rupture triggers the formation of a localized, platelet-rich clot with resultant vessel occlusion and subsequent infarction. Atherosclerotic plaques in humans contain large amounts of TF and it has been suggested that after plaque rupture, TF triggers activation of the clotting system that contributes to the formation of an occlusive clot.

Several studies have targeted TF in animal models of arterial thrombosis in an attempt to reduce arterial thrombosis. These models used a variety of procedures to induce arterial thrombosis principally through damage to the endothelium with subsequent exposure of vessel wall TF to circulating blood. Inhibition of the TF/FVIIa complex in these models reduces or prevents arterial thrombosis. For example, inhibition of TF with a monoclonal anti-rabbit TF antibody in a rabbit model of electrical induction of endothelial injury prevented arterial thrombus formation.39,40 In addition, using a balloon catheter endothelial injury model, recombinant tissue factor pathway inhibitor (rTFPI), an inhibitor of the TF/ FVIIa complex, reduced thrombosis in the coronary artery of pigs and thoracic aorta of rabbits.40,41 While the aforementioned experiments demonstrate the significance of TF in arterial thrombosis, other groups have examined the cellular source of TF in precipitation of thrombosis. Day and colleagues found that vessel wall TF rather than hematopoietic cellderived TF triggered thrombosis in a macrovascular (carotid artery) mouse model.42 In addition, Wang and colleagues recently demonstrated a reduction in carotid arterial thrombosis in mice with a selective deletion of the TF gene in vascular smooth muscle cells. 43 These data indicate that perivascular and not circulating TF is the critical mediator of arterial thrombosis in healthy mice. However, further studies are needed that utilize mice with elevated levels of circulating TF. Taken together, these studies indicate that inhibition of TF represents a novel clinical approach to abrogating arterial thrombosis.

\section{Venous thrombosis}

In contrast to arterial thrombosis which appears to be primarily caused by TF exposed by vessel injury or plaque rupture, VTE typically occurs in the absence of gross vessel wall disruption. Rather, the pathogenesis of VTE appears multi-factorial and involves factors related to Virchow's Triad, namely: (1) alterations in blood flow or stasis; (2) vascular endothelial cell activation; and (3) alterations in the constituents of blood. Immobility, drugs, pregnancy, morbid obesity, and inherited thrombophilic states all increase the risk of VTE through Virchow's Triad. ${ }^{44}$ Elevated levels of circulating TF may be a predominant initiator of VTE. Several groups have demonstrated that patients with VTE have increased levels of TF antigen and activity.45,46 Our group reported that in healthy mice hematopoietic cell-derived TF did not contribute to VTE in an inferior vena cava ligation model.42 However, Biro and colleagues demonstrated that MP isolated from pericardial blood of cardiac surgery patients promoted TF-dependent VTE in a rat model. ${ }^{47}$

VTE is the second leading cause of mortality in cancer patients. Several recent studies have suggested a role for $\mathrm{TF}^{+} \mathrm{MP}$ in the pathogenesis of cancer-related VTE. A retrospective analysis by Tesselaar and colleagues noted elevated levels $\mathrm{TF}^{+} \mathrm{MP}$ activity in patients with breast and pancreatic cancers. ${ }^{48}$ Other retrospective studies found significantly elevated levels of $\mathrm{TF}^{+} \mathrm{MP}$ activity in cancer patients with VTE versus cancer patients without VTE. 49,50 In a prospective study our group found that in a cohort of 11 pancreatic cancer patients, the 2 patients with the highest levels of $\mathrm{TF}$ antigen and $\mathrm{TF}^{+} \mathrm{MP}$ activity in serial samples subsequently developed VTE. ${ }^{51}$ In aggregate these studies suggest that $\mathrm{TF}^{+} \mathrm{MP}$ activity may 
serve as a predictive biomarker for evaluating VTE risk in cancer patients. Other groups have analyzed levels of circulating TF in mouse tumor models and their data would suggest that tumor-derived circulating TF activates the clotting cascade in mice and may promote thrombosis in cancer patients. ${ }^{52,53}$

\section{Disseminated intravascular coagulation}

It has become increasingly clear that there is significant crosstalk between coagulation and inflammation. This association is particularly apparent in models of endotoxemia, severe sepsis and DIC. This is characterized by an uncontrolled and excessive production of thrombin resulting in diffuse and systemic intravascular fibrin deposition and a consumptive coagulopathy. ${ }^{54}$ In sepsis, activation of the clotting system is mediated by TF expression by monocytes and possibly endothelial cells. ${ }^{55,56}$ Other conditions associated with DIC are severe trauma, including surgery and burn injury. ${ }^{54}$

The critical role TF plays in the activation of coagulation and inflammation in DIC and severe sepsis has been demonstrated in several experiments. Humans treated with low doses of LPS were found to have TF expression on monocytes, increased levels of $\mathrm{TF}^{+} \mathrm{MP}$ and increased generation of thrombin. ${ }^{56,57}$ In addition, primate models of endotoxin-induced septic shock have examined the role of TF in DIC. In several studies, baboons were injected with live Escherichia coli to induce septic shock. Animals that were treated with either an inhibitory monoclonal TF antibody ${ }^{58}$, rTFPI ${ }^{59}$ or FVIIa inhibitor ${ }^{60}$ were protected from DIC and death. Other animal models have likewise demonstrated that various strategies to prevent activation of coagulation by the TF/FVIIa complex reduce DIC. ${ }^{61-63}$ Recently our lab found that low TF mice have reduced levels of thrombin-antithrombin complex, a marker of activation of coagulation, and IL-6 compared with control mice in an endotoxemia model. ${ }^{27}$ This study suggested that TF contributes to both coagulation and inflammation in a mouse model of endotoxemia.

A family of G-protein-coupled protease activated receptors (PARs) are emerging as critical mediations in the interactions between coagulation and inflammation. To date, four PARs (1-4) have been characterized, each of which are activated by different proteases. Inflammation may be enhanced by the TF pathway via generation of proteases (TF/FVIIa, FXa and thrombin) that subsequently activate PAR1 and PAR2. These interactions have recently be reviewed by van der Poll. ${ }^{64}$ Niessen and colleagues reported that endotoxemic PAR $1^{-1-}$ mice expressed lower levels of IL- 6 and exhibited decreased mortality compared with wild-type mice. ${ }^{65}$ Their results also indicated that inhibition of thrombin in mice was protective. Additional studies demonstrated that TF-dependent thrombin generation and PAR-1 signaling in dendritic cells amplifies both inflammation and coagulation. ${ }^{65}$

\section{Mouse models}

The pleiotropic effects of TF on different pathways have been difficult to study because inhibition of TF in mice induces hemorrhage and a knock-out of the TF gene is embryonically lethal. Recently our ability to study the role of TF in various physiologic processes has been expanded with the addition of new genetically engineered mice. There are significant differences in the primary amino acid sequence of human and murine TF, particularly in exon 3 of the extracellular domain. ${ }^{66}$ This domain participates in FVII/FVIIa binding and the sequence differences are reflected in the fact that mouse TF binds human FVIIa with reduced affinity compared with mouse FVIIa. ${ }^{67}$ In contrast, human TF binds mouse FVIIa with a similar affinity compared with human FVIIa which has made it possible to replace mouse TF with human TF in mouse models. ${ }^{67}$ 
The following section will briefly describe these mouse models and their contribution to our current understanding of the role of TF in coagulation and inflammation. The first mouse line that was developed expresses human TF from a transgene containing $2 \mathrm{kbp}$ of the human TF promoter and a human TF mini-gene in a mouse TF null background. These animals express low levels of human TF in all tissues (1\% of wild type) and are commonly referred to as 'low TF' mice.68 They exhibit spontaneous hemorrhage in specific tissues, including placenta, heart, uterus and lungs, at later time points in life, but are viable.18,69 The second line of mice expresses human TF (HTF) from a human chromosome vector. HTF mice contain the complete TF gene in addition to extensive 5' and 3' flanking elements. $70 \mathrm{HTF}$ mice were crossed into a TF null background such that the only TF expressed is from the human chromosome vector. These mice express normal levels of human TF in all tissues except the heart.70 Recently, Snyder and colleagues developed a mouse line by 'knocking in' human TF cDNA into the murine TF locus.21 These mice are referred to as TF knock-in mice (TFKI) and express TF in all tissues at levels comparable to wild-type controls and exhibit normal hemostasis. Importantly, both HTF and TFKI mice are 'humanized' for TF and are useful models for evaluating the effects of pharmacologic agents directed against human TF.

TF staining of different cell types cannot distinguish between expression by the cell and binding of $\mathrm{TF}^{+}$MPs. This is highlighted in the experiments by Osterud and colleagues. ${ }^{35,71}$ To overcome this limitation we have generated mice with a cell-specific TF gene deletion to directly evaluate the role of TF expression by different cell types in thrombosis and other processes. This was accomplished by making $\mathrm{TF}^{\text {flox/flox }}$ mice that contain a TF gene flanked by loxP sites, and then crossing these with mice expressing the Cre recombinanse under control of various promoters such as: (1) LysM, myeloid specific; (2) platelet factor 4 (PF4), megakaryocyte/platelet specific; (3) Tie-2, endothelial and hematopoietic cells; and (4) SM22, vascular smooth muscle cells (unpublished data).43,70,72 In addition, we can also utilize bone marrow transplantation to further delineate the contribution of TF expression by either hematopoietic cells or non-hematopoietic cells to different disease processes. For example, mice can be generated that express human TF from either hematopoietic cells (using wild-type mice that receive bone marrow from HTF mice) or non-hematopoietic cells (using HTF mice that receive bone marrow from wild-type mice).

\section{TF and APS}

Although aPL are thought to play a direct role in the hypercoagulability of antiphospholipid syndrome (APS), the exact pathophysiology remains unclear. Recent data suggest a role for antibody-mediated induction of TF expression in monocytes and endothelial cells in the pathogenesis of APS.

The majority of aPL target phospholipid binding proteins rather than targeting phospholipids directly. Current evidence suggests that these aPL appear to have a direct prothrombotic effect. Ginsburg and colleagues demonstrated that aPL titer correlates with thrombosis risk.

${ }^{73}$ Several groups have also shown that passive transfer of aPL induces thrombosis in animal models. $^{74,75}$

While the exact mechanisms underlying this hypercoagulable state are yet to be fully elucidated, it has been proposed that aPL stimulates TF expression within the vasculature and in blood cells, thereby leading to increased thrombosis. Several authors have reported increased monocyte TF expression in patients with APS. ${ }^{76-78}$ Furthermore, de Prost and colleagues have demonstrated that patients with APS had increased monocyte procoagulant activity ${ }^{79}$ In addition, Nojima and colleagues recently reported a strong positive correlation between monocyte TF expression in patients with systemic lupus erythematosis and a 
history of thrombosis. ${ }^{80}$ Several in vitro experiments also support a key role for aPL in the induction of TF expression on monocytes..$^{81-84}$ Other in vitro studies demonstrated that aPL were able to induce expression of TF, proinflammatory cytokines and adhesion molecules in endothelial cells. ${ }^{85,86}$

One generally accepted hypothesis for aPL-induced TF expression involves interaction of aPL with target cell surface receptors and a subsequent increase in TF expression and release of $\mathrm{TF}^{+} \mathrm{MP}$, thereby promoting thrombosis (Figure 1). Identification of the cell surface receptor(s) and the intracellular signaling pathway(s) involved is an active area of research. Currently there are data to suggest several potential cell surface receptor candidates that include annexin A2 (endothelial and monocytes),84,87,88 lipoprotein receptor-related protein (LRP) family (platelets),89 Toll-like receptor 4 (TLR4) (endothelial and monocytes) $90^{-} 92$ and C5a receptor (neutrophils).34,72 In addition, there are experimental data that describe three major intracellular signaling pathways involved in the cellular response to aPL. These include the nuclear factor- $\mathrm{kB}(\mathrm{NF}-\mathrm{kB})$ pathway, $93^{-} 95$ the Ras-Erk pathway96,97 and the p38 mitogen-activated protein (MAP) kinase pathway. 95,98,99 These data suggest that multiple receptors and signaling pathways are involved in aPL-induced TF expression in APS. Of note, several of these experiments were specific for aPL directed against the phospholipid-binding plasma protein, $\beta_{2}$-glycoprotein I $\left(\beta_{2} \mathrm{GPI}\right)$, which along with prothrombin is one of the most common and best characterized antigens. These receptors and pathways have been reviewed recently. ${ }^{99}, 100$

There are recent data to support an integral role for complement activation of TF expression in APS. Using a variety of methods including the use of $\mathrm{TF}^{\mathrm{flox} / \mathrm{flox}} / \mathrm{LysM}^{\mathrm{Cre}}$ mice (which do not express TF on myeloid cells), we were able to demonstrate that complement activation is a critical early mediator linking aPL to fetal loss in a mouse model of APS. ${ }^{72,101,102}$ This has been reviewed recently.103 Notably these data suggest that complement activation of TF expression in neutrophils and subsequent generation of reactive oxygen species is one of the principle mediators of fetal loss in APS in a mouse model.

Seshan and colleagues recently described a novel mouse model of aPL-induced thrombotic microangiopathy (TMA) and reported that both complement-dependent and complementindependent mechanisms were responsible for glomerular injury in their model. ${ }^{104}$ In addition, they note that low TF mice and wild-type mice treated with pravastatin, which downregulates glomerular TF synthesis, were protected from aPL-induced TMA.

Our expanding knowledge of TF in sepsis, inflammation and thrombosis may direct our future treatment of APS. Our current backbone for treatment of thrombosis in APS is the anticoagulant warfarin. While anticoagulation with this agent certainly decreases levels of functional FVII, it does so in a relatively non-specific manner thereby increasing the potential for adverse effects. Directly or indirectly targeting TF is an attractive option for the prevention or treatment of thrombosis associated with APS. In addition to evaluating TFspecific inhibitors, such as TFPI, anti-TF antibodies and inactivated FVIIa in APS, there are also data to support further investigation of currently available medications as adjunct treatments for APS such as the statins. Statins, or hydroxymethylglutaryl CoA reductase inhibitors, have been principally developed and used for their lipid-lowering effects in vascular disease. However, statins also possess a number of other beneficial effects not related to their lipid-lowering including anti-inflammatory activity. There are data to suggest that treatment with statins decrease TF expression and TF-dependent thrombin generation in a number of in vitro and in vivo models. ${ }^{105-107}$. Similarly, there are several medications that have provocative in vitro data, including dilazep (an adenosine uptake inhibitor), defibrotide (single-stranded deoxyribonucleic acid derivative), ACE inhibitors, histone deacetylase 
inhibitors and pentoxifylline. Further in vivo studies are needed to determine if these agents will be useful in the treatment of thrombosis in APS patients.

\section{Conclusion}

It is becoming increasingly apparent that TF functions not only as the critical initiator of in vivo thrombosis but also participates in several other biological processes such as inflammation. Our understanding of TF has been expanded recently by studies with genetic animal models. This understanding will hopefully allow us to specifically and safely target $\mathrm{TF}$ in various disease states such as APS.

\section{Acknowledgments}

This work was supported in part by a grant from the National Institutes of Health as well as a National Hemophilia Foundation-Baxter Fellowship.

\section{References}

1. Broze GJ Jr, Leykam JE, Schwartz BD, Miletich JP. Purification of human brain tissue factor. J Biol Chem 1985;260:10917-10920. [PubMed: 3928626]

2. Spicer EK, Horton R, Bloem L, et al. Isolation of cDNA clones coding for human tissue factor: primary structure of the protein and cDNA. Proc Natl Acad Sci U S A 1987;84:5148-5152. [PubMed: 3037536]

3. Morrissey JH, Fakhrai H, Edgington TS. Molecular cloning of the cDNA for tissue factor, the cellular receptor for the initiation of the coagulation protease cascade. Cell 1987;50:129-135. [PubMed: 3297348]

4. Mackman N, Morrissey JH, Fowler B, Edgington TS. Complete sequence of the human tissue factor gene, a highly regulated cellular receptor that initiates the coagulation protease cascade. Biochemistry 1989;28:1755-1762. [PubMed: 2719931]

5. Banner DW, D'Arcy A, Chene C, et al. The crystal structure of the complex of blood coagulation factor VIIa with soluble tissue factor. Nature 1996;380:41-46. [PubMed: 8598903]

6. Komiyama Y, Pedersen AH, Kisiel W. Proteolytic activation of human factors IX and X by recombinant human factor VIIa: effects of calcium, phospholipids, and tissue factor. Biochemistry 1990;29:9418-9425. [PubMed: 2248955]

7. Mackman N. Regulation of the tissue factor gene. FASEB J 1995;9:883-889. [PubMed: 7615158]

8. Osterud B, Bjorklid E. Sources of tissue factor. Semin Thromb Hemost 2006;32:11-23. [PubMed: 16479458]

9. Drake TA, Morrissey JH, Edgington TS. Selective cellular expression of tissue factor in human tissues. Implications for disorders of hemostasis and thrombosis. Am J Pathol 1989;134:1087-1097. [PubMed: 2719077]

10. Butenas S, Bouchard BA, Brummel-Ziedins KE, Parhami-Seren B, Mann KG. Tissue factor activity in whole blood. Blood 2005;105:2764-2770. [PubMed: 15604222]

11. Giesen PL, Rauch U, Bohrmann B, et al. Blood-borne tissue factor: another view of thrombosis. Proc Natl Acad Sci U S A 1999;96:2311-2315. [PubMed: 10051638]

12. Nemerson Y. A different view of thrombosis. Blood Coagul Fibrinolysis 2000;11 Suppl 1:S1-S2. [PubMed: 10850555]

13. Mackman N. Alternatively spliced tissue factor - one cut too many? Thromb Haemost 2007;97:58. [PubMed: 17200762]

14. Hoffman M, Whinna HC, Monroe DM. Circulating tissue factor accumulates in thrombi, but not in hemostatic plugs. J Thromb Haemost 2006;4:2092-2093. [PubMed: 16961625]

15. Fleck RA, Rao LV, Rapaport SI, Varki N. Localization of human tissue factor antigen by immunostaining with monospecific, polyclonal anti-human tissue factor antibody. Thromb Res 1990;59:421-437. [PubMed: 2237820] 
16. Flossel C, Luther T, Muller M, Albrecht S, Kasper M. Immunohistochemical detection of tissue factor (TF) on paraffin sections of routinely fixed human tissue. Histochemistry 1994;101:449_ 453. [PubMed: 7960944]

17. Mackman N, Sawdey MS, Keeton MR, Loskutoff DJ. Murine tissue factor gene expression in vivo. Tissue and cell specificity and regulation by lipopolysaccharide. Am J Pathol 1993;143:7684. [PubMed: 8317556]

18. Erlich J, Parry GC, Fearns C, et al. Tissue factor is required for uterine hemostasis and maintenance of the placental labyrinth during gestation. Proc Natl Acad Sci U S A 1999;96:81388143. [PubMed: 10393961]

19. Eddleston M, de la Torre JC, Oldstone MB, Loskutoff DJ, Edgington TS, Mackman N. Astrocytes are the primary source of tissue factor in the murine central nervous system. A role for astrocytes in cerebral hemostasis. J Clin Invest 1993;92:349-358. [PubMed: 8326003]

20. Mackman N. Tissue-specific hemostasis in mice. Arterioscler Thromb Vasc Biol 2005;25:22732281. [PubMed: 16123318]

21. Snyder LA, Rudnick KA, Tawadros R, et al. Expression of human tissue factor under the control of the mouse tissue factor promoter mediates normal hemostasis in knock-in mice. J Thromb Haemost 2008;6:306-314. [PubMed: 18005233]

22. Carmeliet P, Mackman N, Moons L, et al. Role of tissue factor in embryonic blood vessel development. Nature 1996;383:73-75. [PubMed: 8779717]

23. Bugge TH, Xiao Q, Kombrinck KW, et al. Fatal embryonic bleeding events in mice lacking tissue factor, the cell-associated initiator of blood coagulation. Proc Natl Acad Sci U S A 1996;93:62586263. [PubMed: 8692802]

24. Toomey JR, Kratzer KE, Lasky NM, Stanton JJ, Broze GJ Jr. Targeted disruption of the murine tissue factor gene results in embryonic lethality. Blood 1996;88:1583-1587. [PubMed: 8781413]

25. Mackman N, Tilley RE, Key NS. Role of the extrinsic pathway of blood coagulation in hemostasis and thrombosis. Arterioscler Thromb Vasc Biol 2007;27:1687-1693. [PubMed: 17556654]

26. Morel O, Toti F, Hugel B, et al. Procoagulant microparticles: disrupting the vascular homeostasis equation? Arterioscler Thromb Vasc Biol 2006;26:2594-2604. [PubMed: 16990554]

27. Pawlinski R, Pedersen B, Schabbauer G, et al. Role of tissue factor and protease-activated receptors in a mouse model of endotoxemia. Blood 2004;103:1342-1347. [PubMed: 14576054]

28. Zillmann A, Luther T, Muller I, et al. Platelet-associated tissue factor contributes to the collagentriggered activation of blood coagulation. Biochem Biophys Res Commun 2001;281:603-609. [PubMed: 11181090]

29. Panes O, Matus V, Saez CG, Quiroga T, Pereira J, Mezzano D. Human platelets synthesize and express functional tissue factor. Blood 2007;109:5242-5250. [PubMed: 17347408]

30. Schwertz H, Tolley ND, Foulks JM, et al. Signal-dependent splicing of tissue factor pre-mRNA modulates the thrombogenicity of human platelets. J Exp Med 2006;203:2433-2440. [PubMed: 17060476]

31. Del Conde I, Shrimpton CN, Thiagarajan P, Lopez JA. Tissue-factor-bearing microvesicles arise from lipid rafts and fuse with activated platelets to initiate coagulation. Blood 2005;106:16041611. [PubMed: 15741221]

32. Maugeri N, Brambilla M, Camera M, et al. Human polymorphonuclear leukocytes produce and express functional tissue factor upon stimulation. J Thromb Haemost 2006;4:1323-1330. [PubMed: 16706978]

33. Moosbauer C, Morgenstern E, Cuvelier SL, et al. Eosinophils are a major intravascular location for tissue factor storage and exposure. Blood 2007;109:995-1002. [PubMed: 17003379]

34. Ritis K, Doumas M, Mastellos D, et al. A novel C5a receptor-tissue factor cross-talk in neutrophils links innate immunity to coagulation pathways. J Immunol 2006;177:4794-4802. [PubMed: 16982920]

35. Egorina EM, Sovershaev MA, Olsen JO, Osterud B. Granulocytes do not express but acquire monocyte-derived tissue factor in whole blood: evidence for a direct transfer. Blood 2008;111:1208-1216. [PubMed: 17947506]

36. Bach RR. Tissue factor encryption. Arterioscler Thromb Vasc Biol 2006;26:456-461. [PubMed: 16397140] 
37. Chen VM, Ahamed J, Versteeg HH, Berndt MC, Ruf W, Hogg PJ. Evidence for activation of tissue factor by an allosteric disulfide bond. Biochemistry 2006;45:12020-12028. [PubMed: 17002301]

38. Bach RR, Monroe D. What is wrong with the allosteric disulfide bond hypothesis? Arterioscler Thromb Vasc Biol 2009;29:1997-1998. [PubMed: 19923558]

39. Speidel CM, Thornton JD, Meng YY, Eisenberg PR, Edgington TS, Abendschein DR. Procoagulant activity on injured arteries and associated thrombi is mediated primarily by the complex of tissue factor and factor VIIa. Coron Artery Dis 1996;7:57-62. [PubMed: 8773434]

40. Pawashe AB, Golino P, Ambrosio G, et al. A monoclonal antibody against rabbit tissue factor inhibits thrombus formation in stenotic injured rabbit carotid arteries. Circ Res 1994;74:56-63. [PubMed: 8261595]

41. Roque M, Reis ED, Fuster V, et al. Inhibition of tissue factor reduces thrombus formation and intimal hyperplasia after porcine coronary angioplasty. J Am Coll Cardiol 2000;36:2303-2310. [PubMed: 11127477]

42. Day SM, Reeve JL, Pedersen B, et al. Macrovascular thrombosis is driven by tissue factor derived primarily from the blood vessel wall. Blood 2005;105:192-198. [PubMed: 15339841]

43. Wang L, Miller C, Swarthout RF, Rao M, Mackman N, Taubman MB. Vascular smooth musclederived tissue factor is critical for arterial thrombosis after ferric chloride-induced injury. Blood 2009;113:705-713. [PubMed: 18931346]

44. Esmon CT. Basic mechanisms and pathogenesis of venous thrombosis. Blood Rev 2009;23:225229. [PubMed: 19683659]

45. Himber J, Kling D, Fallon JT, Nemerson Y, Riederer MA. In situ localization of tissue factor in human thrombi. Blood 2002;99:4249-4250. [PubMed: 12043697]

46. Kamikura Y, Wada H, Nobori T, et al. Elevated levels of leukocyte tissue factor mRNA in patients with venous thromboembolism. Thromb Res 2005;116:307-312. [PubMed: 16038715]

47. Biro E, Sturk-Maquelin KN, Vogel GM, et al. Human cell-derived microparticles promote thrombus formation in vivo in a tissue factor-dependent manner. J Thromb Haemost 2003;1:25612568. [PubMed: 14738565]

48. Tesselaar ME, Romijn FP, Van Der Linden IK, Prins FA, Bertina RM, Osanto S. Microparticleassociated tissue factor activity: a link between cancer and thrombosis? J Thromb Haemost 2007;5:520-527. [PubMed: 17166244]

49. Tesselaar ME, Romijn FP, van der Linden IK, Bertina RM, Osanto S. Microparticle-associated tissue factor activity in cancer patients with and without thrombosis. J Thromb Haemost 2009;7:1421-1423. [PubMed: 19500241]

50. Manly DA, Wang J, Glover SL, et al. Increased microparticle tissue factor activity in cancer patients with venous thromboembolism. Thromb Res. 2009 epub ahead or print.

51. Khorana AA, Francis CW, Menzies KE, et al. Plasma tissue factor may be predictive of venous thromboembolism in pancreatic cancer. J Thromb Haemost 2008;6:1983-1985. [PubMed: 18795992]

52. Yu JL, May L, Lhotak V, et al. Oncogenic events regulate tissue factor expression in colorectal cancer cells: implications for tumor progression and angiogenesis. Blood 2005;105:1734-1741. [PubMed: 15494427]

53. Davila M, Amirkhosravi A, Coll E, et al. Tissue factor-bearing microparticles derived from tumor cells: impact on coagulation activation. J Thromb Haemost 2008;6:1517-1524. [PubMed: 18433463]

54. Levi M. Current understanding of disseminated intravascular coagulation. Br J Haematol 2004;124:567-576. [PubMed: 14871243]

55. Sase T, Wada H, Nishioka J, et al. Measurement of tissue factor messenger RNA levels in leukocytes from patients in hypercoagulable state caused by several underlying diseases. Thromb Haemost 2003;89:660-665. [PubMed: 12669120]

56. Franco RF, de Jonge E, Dekkers PE, et al. The in vivo kinetics of tissue factor messenger RNA expression during human endotoxemia: relationship with activation of coagulation. Blood 2000;96:554-559. [PubMed: 10887118]

57. Aras O, Shet A, Bach RR, et al. Induction of microparticle- and cell-associated intravascular tissue factor in human endotoxemia. Blood 2004;103:4545-4553. [PubMed: 14988149] 
58. Taylor FB Jr, Chang A, Ruf W, et al. Lethal E. coli septic shock is prevented by blocking tissue factor with monoclonal antibody. Circ Shock 1991;33:127-134. [PubMed: 2044206]

59. Carr C, Bild GS, Chang AC, et al. Recombinant E. coli-derived tissue factor pathway inhibitor reduces coagulopathic and lethal effects in the baboon gram-negative model of septic shock. Circ Shock 1994;44:126-137. [PubMed: 7600636]

60. Taylor FB, Chang AC, Peer G, Li A, Ezban M, Hedner U. Active site inhibited factor VIIa (DEGR VIIa) attenuates the coagulant and interleukin- 6 and -8 , but not tumor necrosis factor, responses of the baboon to LD100 Escherichia coli. Blood 1998;91:1609-1615. [PubMed: 9473226]

61. Levi M, ten Cate H, Bauer KA, et al. Inhibition of endotoxin-induced activation of coagulation and fibrinolysis by pentoxifylline or by a monoclonal anti-tissue factor antibody in chimpanzees. J Clin Invest 1994;93:114-120. [PubMed: 8282778]

62. Biemond BJ, Levi M, ten Cate $\mathrm{H}$, et al. Complete inhibition of endotoxin-induced coagulation activation in chimpanzees with a monoclonal Fab fragment against factor VII/VIIa. Thromb Haemost 1995;73:223-230. [PubMed: 7792734]

63. Warr TA, Rao LV, Rapaport SI. Disseminated intravascular coagulation in rabbits induced by administration of endotoxin or tissue factor: effect of anti-tissue factor antibodies and measurement of plasma extrinsic pathway inhibitor activity. Blood 1990;75:1481-1489. [PubMed: 2317559]

64. van der Poll T. Tissue factor as an initiator of coagulation and inflammation in the lung. Crit Care 2008;12 Suppl 6:S3. [PubMed: 19105796]

65. Niessen F, Schaffner F, Furlan-Freguia C, et al. Dendritic cell PAR1-S1P3 signalling couples coagulation and inflammation. Nature 2008;452:654-658. [PubMed: 18305483]

66. Andrews BS, Rehemtulla A, Fowler BJ, Edgington TS, Mackman N. Conservation of tissue factor primary sequence among three mammalian species. Gene 1991;98:265-269. [PubMed: 1840552]

67. Petersen LC, Norby PL, Branner S, et al. Characterization of recombinant murine factor VIIa and recombinant murine tissue factor: a human-murine species compatibility study. Thromb Res 2005;116:75-85. [PubMed: 15850611]

68. Parry GC, Erlich JH, Carmeliet P, Luther T, Mackman N. Low levels of tissue factor are compatible with development and hemostasis in mice. J Clin Invest 1998;101:560-569. [PubMed: 9449688]

69. Pedersen B, Holscher T, Sato Y, Pawlinski R, Mackman N. A balance between tissue factor and tissue factor pathway inhibitor is required for embryonic development and hemostasis in adult mice. Blood 2005;105:2777-2782. [PubMed: 15598816]

70. Pawlinski R, Tencati M, Holscher T, et al. Role of cardiac myocyte tissue factor in heart hemostasis. J Thromb Haemost 2007;5:1693-1700. [PubMed: 17663739]

71. Osterud B, Olsen JO, Bjorklid E. What is blood borne tissue factor? Thromb Res 2009;124:640641. [PubMed: 19632707]

72. Redecha P, Tilley R, Tencati M, et al. Tissue factor: a link between C5a and neutrophil activation in antiphospholipid antibody induced fetal injury. Blood 2007;110:2423-2431. [PubMed: 17536017]

73. Ginsburg KS, Liang MH, Newcomer L, et al. Anticardiolipin antibodies and the risk for ischemic stroke and venous thrombosis. Ann Intern Med 1992;117:997-1002. [PubMed: 1443986]

74. Blank M, Cohen J, Toder V, Shoenfeld Y. Induction of anti-phospholipid syndrome in naive mice with mouse lupus monoclonal and human polyclonal anti-cardiolipin antibodies. Proc Natl Acad Sci U S A 1991;88:3069-3073. [PubMed: 2014226]

75. Pierangeli SS, Barker JH, Stikovac D, et al. Effect of human IgG antiphospholipid antibodies on an in vivo thrombosis model in mice. Thromb Haemost 1994;71:670-674. [PubMed: 8091396]

76. Reverter JC, Tassies D, Font J, et al. Hypercoagulable state in patients with antiphospholipid syndrome is related to high induced tissue factor expression on monocytes and to low free proteins. Arterioscler Thromb Vasc Biol 1996;16:1319-1326. [PubMed: 8911269]

77. Cuadrado MJ, Lopez-Pedrera C, Khamashta MA, et al. Thrombosis in primary antiphospholipid syndrome: a pivotal role for monocyte tissue factor expression. Arthritis Rheum 1997;40:834-841. [PubMed: 9153543] 
78. Dobado-Berrios PM, Lopez-Pedrera C, Velasco F, Aguirre MA, Torres A, Cuadrado MJ. Increased levels of tissue factor mRNA in mononuclear blood cells of patients with primary antiphospholipid syndrome. Thromb Haemost 1999;82:1578-1582. [PubMed: 10613637]

79. de Prost D, Ollivier V, Ternisien C, Chollet-Martin S. Increased monocyte procoagulant activity independent of the lupus anticoagulant in patients with systemic lupus erythematosus. Thromb Haemost 1990;64:216-221. [PubMed: 2125372]

80. Nojima J, Masuda Y, Iwatani Y, et al. Tissue factor expression on monocytes induced by antiphospholipid antibodies as a strong risk factor for thromboembolic complications in SLE patients. Biochem Biophys Res Commun 2008;365:195-200. [PubMed: 17986380]

81. Kornberg A, Blank M, Kaufman S, Shoenfeld Y. Induction of tissue factor-like activity in monocytes by anti-cardiolipin antibodies. J Immunol 1994;153:1328-1332. [PubMed: 8027560]

82. Amengual O, Atsumi T, Khamashta MA, Hughes GR. The role of the tissue factor pathway in the hypercoagulable state in patients with the antiphospholipid syndrome. Thromb Haemost 1998;79:276-281. [PubMed: 9493575]

83. Reverter JC, Tassies D, Font J, et al. Effects of human monoclonal anticardiolipin antibodies on platelet function and on tissue factor expression on monocytes. Arthritis Rheum 1998;41:14201427. [PubMed: 9704640]

84. Zhou H, Wolberg AS, Roubey RA. Characterization of monocyte tissue factor activity induced by IgG antiphospholipid antibodies and inhibition by dilazep. Blood 2004;104:2353-2358. [PubMed: 15226179]

85. Zhou BY, He JJ. Proliferation inhibition of astrocytes, neurons, and non-glial cells by intracellularly expressed human immunodeficiency virus type 1 (HIV-1) Tat protein. Neurosci Lett 2004;359:155-158. [PubMed: 15050687]

86. Lopez-Pedrera C, Buendia P, Barbarroja N, Siendones E, Velasco F, Cuadrado MJ. Antiphospholipid-mediated thrombosis: interplay between anticardiolipin antibodies and vascular cells. Clin Appl Thromb Hemost 2006;12:41-45. [PubMed: 16444433]

87. Ma K, Simantov R, Zhang JC, Silverstein R, Hajjar KA, McCrae KR. High affinity binding of beta 2-glycoprotein I to human endothelial cells is mediated by annexin II. J Biol Chem 2000;275:15541-15548. [PubMed: 10809787]

88. Zhang J, McCrae KR. Annexin A2 mediates endothelial cell activation by antiphospholipid/antibeta2 glycoprotein I antibodies. Blood 2005;105:1964-1969. [PubMed: 15471954]

89. Pennings MT, van Lummel M, Derksen RH, et al. Interaction of beta2-glycoprotein I with members of the low density lipoprotein receptor family. J Thromb Haemost 2006;4:1680-1690. [PubMed: 16879209]

90. Pierangeli SS, Vega-Ostertag ME, Raschi E, et al. Toll-like receptor and antiphospholipid mediated thrombosis: in vivo studies. Ann Rheum Dis 2007;66:1327-1333. [PubMed: 17261530]

91. Raschi E, Testoni C, Bosisio D, et al. Role of the MyD88 transduction signaling pathway in endothelial activation by antiphospholipid antibodies. Blood 2003;101:3495-3500. [PubMed: 12531807]

92. Sorice M, Longo A, Capozzi A, et al. Anti-beta2-glycoprotein I antibodies induce monocyte release of tumor necrosis factor alpha and tissue factor by signal transduction pathways involving lipid rafts. Arthritis Rheum 2007;56:2687-2697. [PubMed: 17665396]

93. Montiel-Manzano G, Romay-Penabad Z, Papalardo de Martinez E, et al. In vivo effects of an inhibitor of nuclear factor-kappa B on thrombogenic properties of antiphospholipid antibodies. Ann N Y Acad Sci 2007;1108:540-553. [PubMed: 17894019]

94. Bohgaki M, Atsumi T, Yamashita Y, et al. The p38 mitogen-activated protein kinase (MAPK) pathway mediates induction of the tissue factor gene in monocytes stimulated with human monoclonal anti-beta2Glycoprotein I antibodies. Int Immunol 2004;16:1633-1641. [PubMed: 15466912]

95. Yasuda S, Bohgaki M, Atsumi T, Koike T. Pathogenesis of anti-phospholipid antibodies: impairment of fibrinolysis and monocyte activation via the p38 mitogen-activated protein kinase pathway. Immunobiology 2005;210:775-780. [PubMed: 16325497] 
96. Aronovich R, Gurwitz D, Kloog Y, Chapman J. Antiphospholipid antibodies, thrombin and LPS activate brain endothelial cells and Ras-dependent pathways through distinct mechanisms. Immunobiology 2005;210:781-788. [PubMed: 16325498]

97. Lopez-Pedrera C, Buendia P, Cuadrado MJ, et al. Antiphospholipid antibodies from patients with the anti-phospholipid syndrome induce monocyte tissue factor expression through the simultaneous activation of NF-kappaB/Rel proteins via the p38 mitogen-activated protein kinase pathway, and of the MEK-1/ERK pathway. Arthritis Rheum 2006;54:301-311. [PubMed: 16385547]

98. Vega-Ostertag ME, Ferrara DE, Romay-Penabad Z, et al. Role of p38 mitogen-activated protein kinase in antiphospholipid antibody-mediated thrombosis and endothelial cell activation. $\mathrm{J}$ Thromb Haemost 2007;5:1828-1834. [PubMed: 17723121]

99. Lopez-Pedrera C, Buendia P, Aguirre MA, Velasco F, Cuadrado MJ. Antiphospholipid syndrome and tissue factor: a thrombotic couple. Lupus 2006;15:161-166. [PubMed: 16634370]

100. Kinev AV, Roubey RA. Tissue factor in the antiphospholipid syndrome. Lupus 2008;17:952-958. [PubMed: 18827061]

101. Girardi G, Berman J, Redecha P, et al. Complement C5a receptors and neutrophils mediate fetal injury in the antiphospholipid syndrome. J Clin Invest 2003;112:1644-1654. [PubMed: 14660741]

102. Redecha P, Franzke CW, Ruf W, Mackman N, Girardi G. Neutrophil activation by the tissue factor/Factor VIIa/PAR2 axis mediates fetal death in a mouse model of antiphospholipid syndrome. J Clin Invest 2008;118:3453-3461. [PubMed: 18802482]

103. Girardi G, Mackman N. Tissue factor in antiphospholipid antibody-induced pregnancy loss: a pro-inflammatory molecule. Lupus 2008;17:931-936. [PubMed: 18827058]

104. Seshan SV, Franzke CW, Redecha P, Monestier M, Mackman N, Girardi G. Role of tissue factor in a mouse model of thrombotic microangiopathy induced by antiphospholipid antibodies. Blood 2009;114:1675-1683. [PubMed: 19535796]

105. Steiner S, Speidl WS, Pleiner J, et al. Simvastatin blunts endotoxin-induced tissue factor in vivo. Circulation 2005;111:1841-1846. [PubMed: 15824212]

106. Meroni PL, Raschi E, Testoni C, et al. Statins prevent endothelial cell activation induced by antiphospholipid (anti-beta2-glycoprotein I) antibodies: effect on the proadhesive and proinflammatory phenotype. Arthritis Rheum 2001;44:2870-2878. [PubMed: 11762948]

107. Ferrara DE, Swerlick R, Casper K, et al. Fluvastatin inhibits up-regulation of tissue factor expression by antiphospholipid antibodies on endothelial cells. J Thromb Haemost 2004;2:15581563. [PubMed: 15333031] 


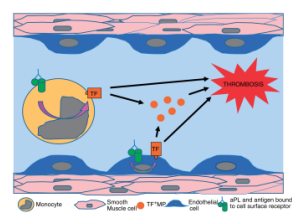

Figure 1.

Tissue factor (TF) induction of thrombosis. Model showing how induction of intravascular TF expression by anti-phospholipid antibody (aPL) may induce thrombosis in antiphospholipid syndrome (APS). aPL and bound antigen interact with cell surface receptors and induce TF expression on monocytes and endothelial cells with resultant increased TF expression and release of TF-positive microparticles (MP). This TF expression within the vasculature and blood may contribute to thrombosis in APS patients. 